\title{
Radiographic Evaluation of the Periapical Status and Technical Quality of Root Canal Fillings Performed by Endodontic Resident of UEM
}

\author{
Análise Radiográfica da Condição Periapical e da Qualidade Técnica das Obturações \\ Realizadas pela Residência em Endodontia da UEM
}

\author{
Isabela Inoue Kussaba ${ }^{\mathrm{a}}$; Marcelo Capitanio ${ }^{\mathrm{a}}$; Esthela Maria Pereira Castanheiro ${ }^{\mathrm{b}}$; Nair Narumi Orita Pavan \\ Marcos Sergio Endo*a
}

\author{
anniversidade Estadual de Maringá, Post-Graduate Studies Program in Integrated Dentistry. PR, Brazil.

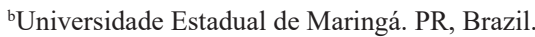 \\ *E-mail: marcossendo@gmail.com
}

\begin{abstract}
Technical quality of endodontic treatment can influence dental prognosis. The aim of the present study was to evaluate radiographically the initial periapical condition and the technical quality of root canal fillings performed by endodontic residents at UEM in 2015 and 2016 . After data collection and descriptive statistics, performed by two independent examiners, the Kappa coefficient was used to assess the agreement between them. The chi-square test was used to verify a possible association of sex, tooth and quality of the restoration, with the presence of a periapical lesion. Most referrals for endodontic treatment were molars $(50.5 \%)$ and female patients $(63.2 \%)$, with a mean age of $39.3( \pm 13.3)$ years. Most teeth were diagnosed with pulp necrosis (44.1\%), and this condition held $74 \%$ of the teeth with chronic periapical lesions. Bone rarefaction was seen mainly in molars $(20 \%)$ and teeth without restorative treatments $(43.5 \%)$. Chi-square test evidenced that sex $(\mathrm{p}=0.303)$, tooth $(\mathrm{p}=0.349)$ and quality of restoration $(\mathrm{p}=0.070)$ were not associated with the presence of periapical bone rarefaction. After finishing the 233 root canal fillings, the apical limit and condensation were satisfactory in $91 \%$ and $100 \%$ of cases, respectively. In conclusion, the presence of chronic periapical lesion was not associated with sex, tooth or quality of the restoration. The root canal fillings performed by endodontic residents was satisfactory.
\end{abstract}

Keywords: Endodontics. Root Canal Therapy. Periapical Periodontitis.

\section{Resumo}

A qualidade técnica do tratamento endodôntico pode influenciar no prognóstico dentário. Este estudo teve como objetivo avaliar radiograficamente a condição periapical inicial e a qualidade técnica das obturações dos canais radiculares realizadas pelos residentes em Endodontia da UEM nos anos de 2015 e 2016. Após a coleta de dados e estatística descritiva, realizada por duas examinadoras independentes, empregou-se o coeficiente Kappa para avaliar a concordância entre as mesmas. O teste de qui-quadrado foi utilizado para verificar uma possivel associação entre as variáveis sexo, tipo dentário e qualidade da restauração, com a presença de lesão. A maioria dos encaminhamentos para atendimento foram molares (50,5\%) e pacientes do sexo feminino (63,2\%), com idade média de 39,3 ( $\pm 13,3)$ anos. Uma grande parcela dos dentes foi diagnosticada com necrose pulpar (44,1\%), sendo que esta condição abrangeu 74\% dos dentes com lesão periapical crônica. A rarefação óssea foi visualizada sobretudo em molares (20\%) e dentes sem tratamentos restauradores (43,5\%). Por meio do teste de quiquadrado, houve evidencias amostrais de que o sexo $(p=0,303)$, o tipo dentário $(p=0,349)$ e a qualidade da restauração ( $p=0,070)$ não estiveram associados à presença da rarefação óssea periapical. Após a finalização dos tratamentos e um total de 233 canais obturados, o limite apical e a condensação da obturação se mostraram satisfatórios em $91 \%$ e 100\% dos casos, respectivamente. Conclui-se que a presença da lesão periapical crônica não esteve associada ao sexo, tipo dentário ou qualidade da restauração. A obturação dos canais radiculares realizada pelos residentes em Endodontia se mostrou satisfatória.

Palavras-chave: Endodontia. Tratamento do Canal Radicular. Periodontite Periapical.

\section{Introduction}

Endodontic treatment is related to the prevention and control of pulp and peri radicular infection ${ }^{1}$. The objective is to ensure effective cleaning of root canals in order to eliminate micro-organisms and tissue debris and, at the same time, to create morphological and dimensional conditions to perform correct filling ${ }^{2}$.

Among the existing stages, filling comprises filling of the instrumented portion of the root canal with materials that promote a three-dimensional sealing and stimulate, or do not interfere with the periapical repair process. The success of this therapy is directly related to the quality of root canal filling, since hermetic sealing prevents bacterial access and makes microorganism survival impossible ${ }^{3-5}$.

The radiographic aspect has been considered a traditional method of assessing the filling quality in endodontic practice. Radiographic images also indicate presence or absence of periapical bone rarefaction or coronary infiltration, which is an important diagnostic resource. Previous studies have employed the use of periapical radiographs6-9.

The prevalence of endodontically treated teeth associated or not with chronic periapical lesion has been evaluated ${ }^{9-12}$. It is known that radiographic aspects such as the filling density and its apical limit may interfere with the endodontic treatment 
success ${ }^{13}$. When the canal density filling is inadequate, $60 \%$ to $70 \%$ of teeth were associated with chronic periapical lesion ${ }^{5,9,14,15}$. It is important to emphasize that when the filling apical limit and its density are adequate, less than $30 \%$ of the teeth were associated with the presence of chronic periapical lesion 5 .

Knowing that the endodontic treatment failure is closely related to inadequate root canal filling ${ }^{7,8}$, it is appropriate to carry out a careful investigation of the fillings technical quality by means of radiographic images.

The objective of this study was to evaluate radiographically the technical quality of root canal fillings, endodontic treatments performed at the Endodontics Residency program of the State University of Maringá (UEM), and to associate the prevalence of chronic periapical lesion with tooth, sex and quality of restoration variables.

\section{Material and Methods}

This study was approved by the Permanent Ethics Committee in Human Research (COPEP) of EMU with, legal opinion of 2.059.127. After approval, medical records of patients over 18 years of age were selected, submitted to endodontic treatments at the Residency Program in Endodontics of UEM in the years 2015 and 2016. Any records with missing information, or with poorly processed, framed inadequately radiographs, or inexistent initial and/or final radiographs were excluded.

General information was collected regarding sex (female and male), age and pulp diagnosis (irreversible pulpitis, pulp necrosis, previously treated, previously started therapy or unidentified diagnosis). In addition, periapical radiographs were analyzed before and after root canal filling; A total of 95 records and 111 teeth were analyzed.

All the radiographs were listed to maintain the blind character of the two independent evaluators. Two undergraduate students from the Dentistry degree of UEM individually analyzed the radiographs.

In the analysis of initial periapical radiographs, information was extracted such as:

1. Dental type (anterior, pre-molar or molar).

2. Apical condition: normal apical tissues (normal periodontal ligament space and intact lamina dura) and presence of periapical bone rarefaction (changes in the periodontal ligament space, loss of lamina dura integrity, moderate to severe alteration in bone structure with well-defined radiolucent areas).

3. Quality of restorations (absent, adequate, inadequate).

After the filling was finalized, the following aspects were analyzed by periapical radiographs ${ }^{16}$ :

I. Number of canals filled.

II. Apical filling limit in each canal.

- Sub-filling: when the filling was more than $2 \mathrm{~mm}$ below the radiographic vertex.

- Ideal filling: when the filling was between 0 and $2 \mathrm{~mm}$ below the radiographic vertex.
- Overfilling: when the filling material has surpassed the radiographic vertex.

I. Condensation of the filling material in each canal.

- Suitable: homogenously condensed, with no bubbles or empty spaces inside the filling mass, and between it and the root canal wall.

- Inadequate: presenting bubbles or defects in the filling mass or between it and the root canal wall.

\subsection{Data Analysis}

Kappa coefficient was used to examine the concordance between the two evaluators. First, a descriptive data analysis corresponding to the variables investigated was carried out. Chi-square test was used to evaluate the association among the nominal qualitative variables (tooth, sex, quality of restoration) and the presence of chronic periapical lesion. All tests were performed in the R (R Development Core Team, 2017) statistical environment. The significance level adopted was $5 \%$.

\section{Results and Discussion}

\subsection{General data}

The present study analyzed 198 medical records of the Endodontics Residency Service of UEM Dentistry Department of patients submitted to endodontic treatment from 2015 to 2016, of which 103 medical records were excluded because they did not conform to the pre-established inclusion criteria.

From the rest, 95 records were included, with 111 teeth and 233 root canals endodontically treated. The mean age of the patients included in this study was $39.3( \pm 13.3)$ years (Figure 1). A higher prevalence of endodontic treatments was observed in women $(63.2 \%)$. The most treated teeth were molars $(50.5 \%)$, followed by the anterior (26\%) and premolars (23.5).

Figure 1 - Comparative Boxplot of patients' age in groups with and without chronic periapical lesion

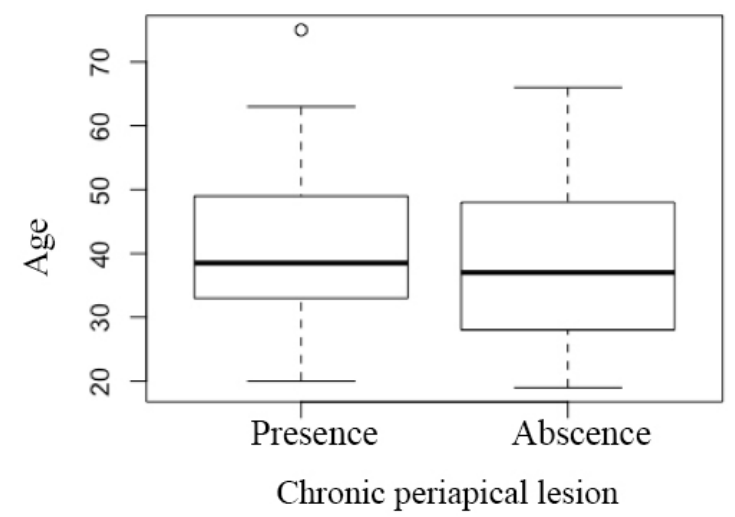

Source: Research data

\subsection{Initial restorative, pulp and periapical condition}

The pulp diagnosis of the teeth analyzed was classified as: irreversible pulpitis, pulp necrosis, previously treated, therapy previously started, or unidentified diagnosis. It was observed 
that $44.1 \%$ were diagnosed with pulp necrosis, predominating over the other conditions. In addition, $74 \%$ of the teeth that exhibited periapical bone rarefaction had pulp necrosis (29 teeth) (Table 1).

Table 1 - Periapical condition regarding the pulp diagnosis of the teeth analyzed

\begin{tabular}{|c|c|c|c|}
\hline \multirow{2}{*}{ Pulp Diagnostics } & \multicolumn{2}{|c|}{$\begin{array}{c}\text { Chronic periapical } \\
\text { lesion }\end{array}$} & \multirow{2}{*}{ Total (\%) } \\
\cline { 2 - 3 } & Present & Absent & \\
\hline Unidentified & 5 & 5 & $10(9 \%)$ \\
\hline Pulp necrosis & 29 & 20 & $49(44.1 \%)$ \\
\hline Irreversible pulpitis & 0 & 45 & $45(40.5 \%)$ \\
\hline Previously treated teeth & 4 & 1 & $5(4.5 \%)$ \\
\hline $\begin{array}{c}\text { Therapy previously } \\
\text { started }\end{array}$ & 1 & 1 & $2(1.9 \%)$ \\
\hline Total & $39(36 \%)$ & $72(64 \%)$ & $111(100 \%)$ \\
\hline
\end{tabular}

Source: Research data

In total, $64 \%$ of the teeth presented normal apical tissue and $36 \%$ presented chronic periapical lesion. Among the teeth with bone rarefaction, most (43.5\%) did not present restorative treatment (17 teeth) (Table 2).
Table 2 - Quality of restoration regarding the periapical diagnosis of the teeth analyzed

\begin{tabular}{|c|c|c|c|c|}
\hline \multirow{2}{*}{\begin{tabular}{|c|} 
Chronic \\
Periapical \\
Lesion
\end{tabular}} & \multicolumn{3}{|c|}{ Quality of the Restoration } & \multirow{2}{*}{ Total (\%) } \\
\hline & Absent & Inadequate & Appropriate & \\
\hline Present & 17 & 7 & 15 & $39(36 \%)$ \\
\hline Absent & 18 & 10 & 44 & $72(64 \%)$ \\
\hline \begin{tabular}{|l|} 
Total $(\%)$ \\
\end{tabular} & $35(31.5 \%)$ & $17(15.5 \%)$ & $59(53 \%)$ & $111(100 \%)$ \\
\hline
\end{tabular}

The teeth which had periapical lesions were molars (20\%), followed by the anterior (18\%) and pre-molars (7,5\%). It was also identified that the female sex comprised $59 \%$ of the teeth characterized by bone rarefaction. However, through the chisquare test, there were sample evidences that the patients' sex $(p=0.303)$, the dental type $(p=0.349)$ and the restoration quality $(p=0.070)$ were not associated with the presence of chronic periapical lesion.

\subsection{Apical filling limit}

Regarding the apical filling limit, 91\% of the canals had ideal filling, while $8.6 \%$ presented sub-filling and $0.4 \%$ had over-filling. Within the sub-filled canals, the largest portion was represented by mesiobuccal canals, and this was also the only type of overfilled canals (Table 3 ).

Table 3 - Number of canals related to the apical filling limit

\begin{tabular}{|c|c|c|c|c|c|c|c|c|c|c|}
\hline \multirow[b]{2}{*}{ apical filling limit } & \multicolumn{9}{|c|}{ Canal } & \multirow[b]{2}{*}{ Total (\%) } \\
\hline & Uni & $\mathbf{V}$ & $\mathbf{P}$ & MV & ML & M & DV & DL & D & \\
\hline Ideal & 37 & 14 & 41 & 42 & 22 & 3 & 26 & 3 & 24 & $212(91 \%)$ \\
\hline Sub-filling & 3 & 1 & 2 & 7 & 2 & 1 & 3 & 0 & 1 & $20(8.6 \%)$ \\
\hline Over-filling & 0 & 0 & 0 & 1 & 0 & 0 & 0 & 0 & 0 & $1(0.4 \%)$ \\
\hline Total & 40 & 15 & 43 & 50 & 24 & 4 & 29 & 3 & 25 & $233(100 \%)$ \\
\hline
\end{tabular}

Source: Research data

\subsection{Condensation of the filling material}

As for the condensation of the filling material, in 100\% of the final radiographs analyzed, the filling mass was adequately compressed. Kappa coefficient was 0.86 .

\subsection{Discussion}

A higher prevalence of endodontic treatments was observed in women $(63.2 \%)$. These results are compatible with previous studies, in which a greater number of treatments were identified in female patients ${ }^{13,16-18}$. In addition, the mean age of $39.3( \pm 13.3)$ years observed in the present study is a behavior observed in the literature. Ferreira et al. ${ }^{19}$ found a predominance of treatments performed in patients aged 20 to 59 years. These results may be related to periods of greater demand for teeth maintenance in the oral cavity.

In this study, it was verified that the female sex also included most of the teeth with lesion (59\%). The chisquare test indicated that there was no statistically significant difference, and therefore there was no association between sex and chronic periapical lesion $(\mathrm{p}=0.303)$. Often, the presence of teeth with periapical lesion is greater in women ${ }^{20}$, however, often, there is no association between the two variables ${ }^{21}$.

One of the factors that influence the prognosis of the treatment is the quality of the final coronary sealing, and also between the treatment sessions. ${ }^{21}$ Endodontically treated teeth with coronary restoration have a lower prevalence of bone rarefaction when compared to teeth treated without restoration. Most of the teeth with lesions referred to UEM Endodontics Residency Program did not have restorations, however, there was no association between the quality of the restoration and the presence of periapical lesion $(p=0.070)$.

The percentage of teeth diagnosed with pulp necrosis ranges from $30 \%{ }^{22}$ to $60 \%$ (23). The teeth with pulp necrosis constituted the largest portion (44.1\%) of the teeth received for treatment by the residents, and this condition included $74 \%$ of the teeth with lesion. The periapical bone rarefaction was predominantly characterized in the molars. Molars are the most difficult to treat when compared to anterior and pre-molar teeth $^{18}$ and failure in chemo-mechanical preparation (CMPs) may be a factor for the appearance of periapical lesion. In our study, there was no association between the lesion and the dental type ( $p=0.349)$, however, the mesiobuccal canals of the 
molars were the ones that suffered instrumentation failures the most, and consequently, at the filling.

The treatment result is influenced by the apical filling limit. Researchers indicate that the indicated apical limit ranges from $0 \mathrm{~mm}^{24}, 1 \mathrm{~mm}^{25}, 2 \mathrm{~mm}^{24}$ and $3 \mathrm{~mm}^{25}$. According to the studies by Sjogren et al. ${ }^{4}$ the best prognosis was found for canals in which the filling reached $2 \mathrm{~mm}$ below the apex, and $94 \%$ revealed normal periapical conditions in the followup exam. Regardless of the measurement, an adequate apical stop is essential for the elimination of inflamed and necrosed pulp tissues, and consequent bone repair ${ }^{25}$. In addition, it aims to confine the material inside the canal and to avoid possible cytotoxicity ${ }^{25}$.

In the present study, the total number of teeth with and without lesion was $36 \%$ and $64 \%$, respectively. Chronic periapical lesion is a complex multifactorial condition originated from an infected necrotic pulp or a failed endodontic treatment. It usually develops asymptomatic, and the prognosis is less favorable when detected late. Epidemiological studies on the prevalence of lesions in different countries have revealed that this is a general oral health problem and may compromise the systemic health ${ }^{20}$. New studies in the Brazilian population, investigating different variables are necessary.

\section{Conclusion}

There were evidences that chronic periapical lesion did not show to be associated with tooth, sex and restoration variables in the sample selected by this study. The technical quality of root canal fillings performed by the residents in the years 2016 and 2017 can be verified, and the apical limit and the filling material condensation were satisfactory in $91 \%$ and $100 \%$ of the cases, respectively.

\section{References}

1. Martin G, Azeredo RA. Análise do preparo de canais radiculares utilizando-se a diafanização. Rev Odontol UNESP 2014;43(2): 111-8. doi: http://dx.doi.org/10.1590/ rou. 2014.013

2. Soares IJ, Goldberg F. Endodontia técnicas e fundamentos. São Paulo: Artmed; 2011.

3. Kerekes K, Tronstad L. Long-term results of endodontic treatment performed with a standardized technique. J Endod 1979;5(3):83-90.doi:10.1016/S0099-2399(79)80154-5

4. Sjogren U, Hagglund B, Sundqvist G, Wing K. Factors affecting the long-term results of endodontic treatment. J Endod 1990;16(10):498-504. doi: 10.1016/S00992399(07)80180-4

5. Dugas NN, Lawrence HP, Teplitsky PE, Pharoah MJ, Friedman S. Periapical health and treatment quality assessment of rootfilled teeth in two Canadian populations. Int Endod J 2003 Mar;36(3):181-92. doi: 10.1046/j.1365-2591.2003.00640.x

6. Ray HA, Trope M. Periapical status of endodontically treated teeth in relation to the technical quality of the root filling and the coronal restoration. Int Endod J 1995;28(1):12-8. doi: 10.1111/j.1365-2591.1995.tb00150.x

7. Kirkevang LL, Ørstavik D, Hörsted-Bindslev P, Wenzel
A. Periapical status and quality of root fillings and coronal restorations in a Danish population. Int Endod J 2000;33(6):509-15. doi: 10.1046/j.1365-2591.2000.00381.x

8. Hommez GM, Coppens CR, De Moor RJ. Periapical health related to the quality of coronal restorations and root fillings. Int Endod J 2002;35(8):680-9. doi: 10.1046/j.13652591.2002.00546.x

9. Estrela C, Leles CR, Hollanda AC, Moura MS, Pécora JD. Prevalence and risk factors of apical periodontitis in endodontically treated teeth in a selected population of Brazilian adults. Braz Dent J 2008;19(1):34-9. doi: 10.1590/ s0103-64402008000100006

10. Kirkevang LL, Hörsted-Bindslev P, Ørstavik D, Wenzel A. Frequency and distribution of endodontically treated teeth and apical periodontitis in an urban Danish population. Int Endod J 2001;34(3):198-205. doi: 10.1046/j.13652591.2001.00370.x

11. Lupi-Pegurier L, Bertrand MF, Muller-Bolla M, Rocca JP, Bolla M. Periapical status, prevalence and quality of endodontic treatment in an adult French population. Int Endod J 200235(8):690-7. doi: 10.1046/j.1365-2591.2002.00547.x

12. Tsuneishi M, Yamamoto T, Yamanaka R, Tamaki N, Sakamoto $\mathrm{T}$, Tsuji K, et al. Radiographic evaluation of periapical status and prevalence of endodontic treatment in an adult Japanese population. Oral Surg Oral Med Oral Pathol Oral Radiol Endod 2005;100(5):631-5. doi: 10.1016/j.tripleo.2005.07.029

13. Boucher Y, Matossian L, Rilliard F, Machtou P. Radiographic evaluation of the prevalence and technical quality of root canal treatment in a French subpopulation. Int Endod J 2002;35(3):229-38. doi: 10.1046/j.1365-2591.2002.00469.x

14. Eriksen HM, Bjertness E, Orstavik D. Prevalence and quality of endodontic treatment in an urban adult population in Norway. Dent Traumatol 1988;4(3):122-6. doi: 10.1111/ j.1600-9657.1988.tb00309.x

15. Eriksen HM, Bjertness E. Prevalence of apical periodontitis and results of endodontic treatment in middle-aged adults in Norway. Dent Traumatol 1991;7(1):1-4. doi: 10.1111/j.16009657.1991.tb00174.x

16. Vengerfeldt V, Mändar R, Nguyen MS, Saukas S, Saag M. Apical periodontitis in southern Estonian population: prevalence and associations with quality of root canal fillings and coronal restorations. BMC Oral Health 2017;17:147. doi: 10.1186/s12903-017-0429-7

17. Hollanda ACB, Alencar AHG, Estrela CRA, Bueno MR, Estrela C. Prevalence of endodontically treated teeth in a Brazilian adult population. Braz Dent J 2008;19(4):313-17. doi: 10.1590/S0103-64402008000400005

18. Huumonen S, Suominen AL, Vehkalahti MM. Prevalence of apical periodontitis in root filled teeth: findings from a nationwide survey in Finland. Int Endod J 2017;50(3):22936. doi: 10.1111/iej.12625.

19. Ferreira HLJ, Paula MVQ, Guimarães SMR. Avaliação radiográfica de obturações de canais radiculares. Rev Odonto Ciênc 2007;22(58):340-5.

20. Berlinck T, Tinoco JMM, Carvalho FLF, Sassone LM, Tinoco EMB. Epidemiological evaluation of apical periodontitis prevalence in an urban Brazilian population. Braz Oral Res 2015;29(1):1-7. doi: 10.1590/1807-3107BOR-2015. vol29.0051

21. Al-Nazhan SA, Alsaeed SA, Al-Attas HA, Dohaithem AJ, Al-Serhan MS, Al-Maflehi NS. Prevalence of apical periodontitis and quality of root canal treatment in an adult 
Saudi population. Saudi Med J 2017;38(4):413-21. doi: 10.15537/smj.2017.4.16409.

22. Orstavik D, Hörsted-Bindslev P. A comparison of endodontic treatment results at two dental schools. Int Endod J 1993;26(6):348-54. 10.1111/j.1365-2591.1993.tb00768.x

23. Serene TP, Spolsky VW. Frequency of endodontic therapy in a dental school setting. J Endod 1981;7(8):385-7. doi: 10.1016/S0099-2399(81)80062-3
24. Dovigo LN, Campos JADB, Pappen FG, Leonardo RT. Limite apical de obturação e o sucesso clínico e radiográfico de dentes com necrose pulpar e lesão periapical. RGO 2006;54(3):249-53.

25. Holland R, Valle GF, Taintor JF, Ingle JI. Influence of bony resorption on endodontic treatment. Oral Surg Oral Med Oral Pathol 1983;55(2):191-203. doi: 10.1016/00304220(83)90178-0 